\title{
Miskonsepsi Konsep Gerak Satu dan Dua Dimensi Siswa SMA
}

\author{
Faizatun Nisa' ${ }^{1}$, Lia Yuliati ${ }^{1}$, Nandang Mufti ${ }^{1}$ \\ ${ }^{1}$ Pendidikan Fisika-Universitas Negeri Malang
}

\section{INFO ARTIKEL}

\section{Riwayat Artikel:}

Diterima: 08-05-2019

Disetujui: 22-10-2019

\section{Kata kunci: \\ mastery of concepts; \\ straight motion; \\ parabolic motion; \\ circular motion; \\ penguasaan konsep; \\ gerak lurus; \\ gerak parabola; \\ gerak melingkar}

\section{Alamat Korespondensi:}

Faizatun Nisa'

Pendidikan Fisika

Universitas Negeri Malang

Jalan Semarang 5 Malang

E-mail: lia.yuliati.fmipa@um.ac.id

Kinematika merupakan materi dasar yang dapat digunakan siswa untuk menyelesaikan permasalahan-permasalahan fisika. Sejak massa Galileo dan Newton, kinematika dan dinamika menjadi dasar dalam memahami dunia (Montecinos, dkk, 2018). Kinematika meliputi gerak satu dimensi dan gerak dua dimensi (Meltzer \& Shaffer, 2001). Pemahaman konsep tentang gerak dengan baik akan membantu siswa dalam mempelajari materi selanjutnya, seperti mekanika (Pawl, 2014). Beberapa penelitian menunjukkan terdapat kesulitan yang dialami siswa dalam memahami materi gerak satu dan dua dimensi. Siswa kesulitan dan tidak konsisten dalam menerapkan definisi operasional kecepatan (Taqwa, dkk, 2017), dan percepatan pada persoalan non kalkulus (Sutopo, 2012), menentukan titik acuan dan kecepatan sesaat pada grafik hubungan posisi dan waktu (Bollen, dkk, 2016). Kemampuan menafsirkan kemiringan grafik lebih baik dari pada luasan dibawah kurva kinematika (McDermott, 1987; Ivanjek, dkk, 2016). Siswa menganggap grafik kinematika seperti gambaran sebuah lintasan gerak (Beichner, 1994; Elby, 2000; Planinick, 2013). Banyak profesor yang menganggap percepatan di titik terendah pada pendulum adalah nol (Reif \& Allen, 1992). Siswa berpikir objek tidak memiliki gerakan ke depan ataupun dorongan ketika dilepaskan dari pembawa yang bergerak, (Dilber, dkk, 2009). Akibatnya, benda yang jatuh bergerak mundur atau jatuh lurus ke bawah (Millar \& Kragh, 1994). Mahasiswa pendidikan fisika di Bengkulu menggunakan prinsip Hukum Archimedes, Hukum Newton, hukum kekekalan energi untuk menentukan jarak pada gerak parabola (Sutarno, dkk, 2017).

Kesulitan yang dialami siswa maupun mahasiswa dipengaruhi oleh penguasaan konsep yang masih rendah. Penguasaan konsep merupakan bagian dari hasil komponen pembelajaran konsep, prinsip, dan struktur pengetahuan pada ranah kognitif. Penguasaan konsep fisika merupakan kemampuan siswa dalam memahami konsep atau arti fisis dari konsep dan mengaplikasikan konsep dengan benar (Engelhardt \& Beichner, 2004) berdasarkan struktur kognitif yang dikemukakan Bloom dalam (Anderson, dkk, 2001). Penguasaan konsep merupakan kemampuan siswa dalam memahami makna ilmiah, baik konsep secara teori maupun penerapannya dalam kehidupan sehari-hari (Dahar, 1988). Penguasaan konsep dalam konteks fisika meliputi dimensi kognitif mulai dari C1 sampai C6. Berdasarkan Taksonomi Bloom yang telah direvisi (Anderson, dkk, 2001) dimensi kognitif mencakup enam kriteria, yaitu mengingat $(\mathrm{C} 1)$, memahami $(\mathrm{C} 2)$, menerapkan $(\mathrm{C} 3)$, menganalisis $(\mathrm{C} 4)$, menilai (C5), dan menciptakan (C6). 
Penguasaan konsep merupakan bagian penting dalam proses pemecahan masalah (Sabella \& Redish, 2007) dan merupakan faktor kunci dalam penelitian sains dan teknik khususnya pendidikan fisika (Docktor \& Mestre, 2014;Ceberio, dkk, 2016; Adams \& Wieman, 2015). Beberapa hasil penelitian juga menyatakan bahwa penguasaan konsep yang baik merupakan dasar menyelesaikan permasalahan fisika (Docktor, Strand, dkk, 2015). Kelemahan kerangka konsep akan menjadi penghalang besar dalam memahami fisika sehingga memengaruhi siswa dalam memecahkan masalah fisika (Ceberio, dkk, 2016). Tujuan penelitian ini adalah mengeksplorasi penguasaan konsep siswa pada materi gerak satu dan dua dimensi. Penelitian penting dilakukan dalam rangka memberikan rekomendasi pada praktik pembelajaran fisika di sekolah.

\section{METODE}

Penelitian ini dilaksanakan di salah satu SMA Negeri Bojonegoro pada semester gasal 2018 - 2019. Penelitian untuk mengeksplorasi penguasaan konsep siswa dilaksanakan dengan pendekatan kuantitatif non-eksperimen. Metode survei dilaksanakan pada 113 siswa yang terdiri dari kelas XI dan XII. Pemilihan subjek penelitian berdasarkan siswa yang telah menempuh materi gerak satu dan dua dimensi.

Pengumpulan data dilaksanakan dengan memberikan tes kepada siswa. Tes terdiri dari 20 soal pilihan ganda beralasan dengan taraf kognitif C1, C2, C3, dan C4, sebaran soal ditunjukkan pada tabel 1. Siswa diberi waktu 90 menit untuk mengerjakan soal. Bobot soal benar bernilai 1 dan salah bernilai 0. Soal tes dikembangkan dari soal $F C I$, $M B T$, dan beberapa sumber rujukan lain. Soal berfokus pada penguasaan konsep tentang grafik pada gerak lurus, vektor pada gerak parabola dan melingkar, serta penerapan persamaan besaran fisis dalam gerak satu dan dua dimensi. Data hasil tes dianalisis secara kuantitatif untuk mengetahui nilai rata-rata dan standar deviasi. Data juga dianalisis secara kualitatif dengan mengelompokkan berdasarkan ranah kognitif untuk setiap materi. Alasan yang disampaikan siswa direduksi sesuai konsep yang sesuai dengan soal.

Tabel 1. Sebaran Soal Berdasarkan Ranah Kognitif

\begin{tabular}{|c|c|c|c|}
\hline Materi & Ranah Kognitif & Indikator & Soal ke- \\
\hline Gerak Lurus & $\begin{array}{l}\mathrm{C} 1 \\
\mathrm{C} 2 \\
\mathrm{C} 3 \\
\mathrm{C} 4\end{array}$ & $\begin{array}{l}\text { Mengidentifikasi kecepatan rata-rata benda } \\
\text { Menjelaskan grafik perpindahan dengan waktu } \\
\text { Menunjukkan perbedaan perpindahan dan jarak } \\
\text { Menghitung percepatan rata-rata benda bergerak vertikal } \\
\text { Menganalisis kecepatan dari diagram gerak dua benda } \\
\text { Menganalisis grafik posisi terhadap waktu } \\
\text { Menyeleksi grafik kecepatan terhadap waktu } \\
\text { Menganalisis grafik kecepatan terhadap waktu } \\
\text { Menyeleksi pernyataan yang sesuai dengan gerak jatuh bebas }\end{array}$ & $\begin{array}{l}1 \\
3 \\
2 \\
5 \\
4 \\
6 \\
7 \\
8 \\
9\end{array}$ \\
\hline $\begin{array}{l}\text { Gerak } \\
\text { Parabola }\end{array}$ & $\begin{array}{l}\mathrm{C} 1 \\
\mathrm{C} 2 \\
\mathrm{C} 3 \\
\mathrm{C} 4\end{array}$ & $\begin{array}{l}\text { Mengidentifikasi arah vektor kecepatan pada gerak parabola } \\
\text { Menunjukkan arah kecepatan dan percepatan gerak parabola } \\
\text { Menentukan kecepatan terendah benda pada beberapa titik } \\
\text { Menganalisis kecepatan awal, percepatan, dan waktu benda di udara } \\
\text { Menyeleksi pernyataan tentang besar dan arah kecepatan dan percepatan pada gerak } \\
\text { parabola } \\
\text { Menyeleksi diagram posisi benda di setiap waktu }\end{array}$ & $\begin{array}{l}10 \\
12 \\
15 \\
11 \\
13 \\
14\end{array}$ \\
\hline $\begin{array}{l}\text { Gerak } \\
\text { Melingkar }\end{array}$ & $\begin{array}{l}\mathrm{C} 1 \\
\mathrm{C} 2 \\
\mathrm{C} 3 \\
\mathrm{C} 4\end{array}$ & $\begin{array}{l}\text { Mengidentifikasi arah percepatan pada gerak melingkar } \\
\text { Membandingkan nilai kecepatan linier, kecepatan sudut, dan percepatan pada gerak } \\
\text { melingkar dengan laju konstan } \\
\text { Menghitung kecepatan maksimum pada lintasan melingkar } \\
\text { Menentukan arah kecepatan rata-rata pada gerak melingkar } \\
\text { Menentukan arah percepatan rata-rata pada gerak melingkar }\end{array}$ & $\begin{array}{l}19 \\
16 \\
20 \\
17 \\
18\end{array}$ \\
\hline
\end{tabular}

\section{HASIL}

Data hasil tes didapatkan nilai rata-rata penguasaan konsep gerak satu dan dua dimensi siswa hanya 25,97 dengan standar deviasi 10,08. Nilai rata-rata yang didapatkan memiliki makna rata-rata siswa hanya mampu menjawab 5 dari 20 soal tes. Nilai maksimum yang mampu dicapai siswa hanya 55 yang artinya siswa terbaik mampu menjawab 11 soal tes. Penguasaan konsep siswa diuji dalam ranah kognitif $\mathrm{C} 1, \mathrm{C} 2, \mathrm{C} 3$, dan $\mathrm{C} 4$. Hasil penguasaan konsep siswa dalam setiap ranah kognitif ditunjukkan pada gambar 1 . 


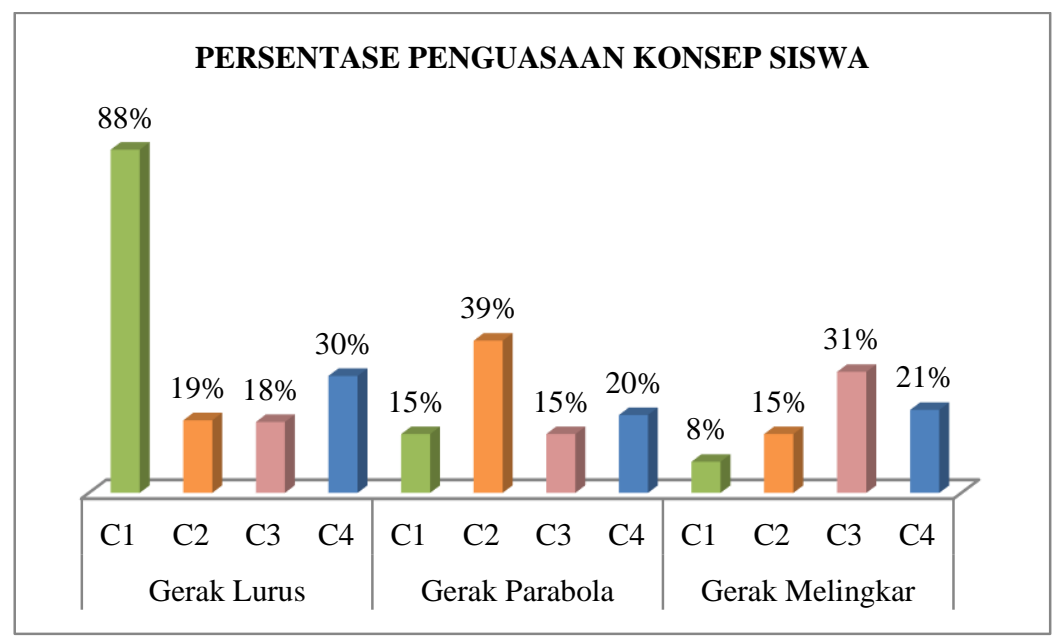

Gambar 1. Penguasaan Konsep Siswa di setiap Ranah Kognitif

Pada materi gerak lurus persentase tertinggi di ranah kognitif $\mathrm{C} 1$, gerak parabola pada $\mathrm{C} 2$, dan gerak melingkar pada C3. Soal gerak lurus dengan ranah kognitif C1 mengenai kecepatan rata-rata benda (Gambar 2). 88\% siswa mengetahui bahwa saat benda memiliki kecepatan rata-rata sama dengan nol maka benda diam. Hasil analisis alasan menunjukkan 13 siswa memilih option B karena menurut mereka kecepatan rata-rata merupakan perubahan kecepatan setiap saat. Akan tetapi, kecepatan rata-rata sama dengan nol juga dapat diartikan benda bergerak namun tidak mengalami perpindahan. Hasil jawaban siswa pada soal nomor 2 menunjukkan hal yang berbeda.

1. Jika kecepatan rata-rata benda sama dengan nol, maka benda dalam keadaan....

A. Diam (99 siswa)

B. Bergerak dengan kecepatan konstan (13 siswa)

C. Bergerak dengan percepatan konstan

D. Bergerak ke arah $\mathrm{x}$ positif

E. Bergerak ke arah y negatif (1 siswa)

\section{Gambar 2. Soal Nomor 1 Ranah Kognitif C1 pada Gerak Lurus}

Hasil analisis jawaban siswa ditemukan beberapa miskonsepsi konsep gerak lurus yang ditunjukkan pada tabel 2. Miskonsepsi siswa dikelompokkan berdasarkan alasan yang diberikan mayoritas siswa.

Tabel 2. Ringkasan Miskonsepsi Konsep Gerak Lurus

\begin{tabular}{|c|c|c|}
\hline Konsep & Konsep yang dimiliki siswa & Persentase \\
\hline Jarak dan Perpindahan & $\begin{array}{l}\text { Jarak dan perpindahan adalah besaran yang sama } \\
\text { Jarak besaran vektor dan perpindahan besaran skalar }\end{array}$ & $\begin{array}{l}62 \% \\
24 \%\end{array}$ \\
\hline Percepatan & Percepatan rata-rata ditentukan dari kelajuan bukan kecepatan & $56 \%$ \\
\hline Diagram Gerak (Gambar 3) & Pada posisi yang sama dua benda memiliki kecepatan rata-rata yang sama & $78 \%$ \\
\hline Grafik Gerak Lurus & $\begin{array}{l}\text { Percepatan pada grafik posisi terhadap waktu dapat ditentukan dengan perpindahan dibagi waktu } \\
\text { kuadrat }\left(a=s / t^{2}\right) \\
\text { Kurva pada grafik posisi terhadap waktu seperti lintasan gerak benda } \\
\text { Kemiringan grafik kecepatan terhadap waktu tidak menunjukkan percepatan }\end{array}$ & $\begin{array}{l}35 \% \\
10 \% \\
18 \%\end{array}$ \\
\hline
\end{tabular}

Penguasaan konsep tentang diagram gerak ditunjukkan gambar 3. Hanya $15 \%$ siswa yang mampu menganalisis diagram gerak lurus. Siswa tidak menerapkan konsep bahwa kecepatan rata-rata dipengaruhi perpindahan pada selang waktu tertentu. Pada soal tentang grafik perpindahan terhadap waktu, siswa menentukan percepatan dengan persamaan $\left(a=s / t^{2}\right)$ karena mempertimbangkan satuan percepatan $\left(\mathrm{m} / \mathrm{s}^{2}\right)$. Pada grafik kecepatan terhadap waktu, $57 \%$ siswa dapat memaknai kemiringan grafik sebagai representasi dari percepatan gerak benda. 
4. Dua balok A dan B bergerak ke kanan pada lintasan lurus. Posisi kedua balok diamati secara serempak selama enam detik dan hasil pengamatan ditunjukkan Gambar 1.

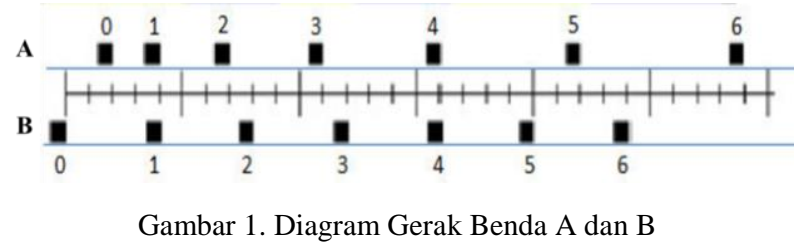

Jika angka nol menunjukkan saat pengamatan dimulai, maka pernahkah kedua balok memiliki kecepatan rata-rata yang sama?

A. Tidak pernah (6 siswa)

B. Pernah, tepat pada saat $\mathrm{t}=1$ ( 3 siswa)

C. Pernah, tepat pada saat $\mathrm{t}=4$ (22 siswa)

D. Pernah, tepat pada $\mathrm{t}=1$ dan $\mathrm{t}=4(63$ siswa)

E. Pernah, selama $\mathrm{t}=2$ sampai $\mathrm{t}=3$ (17 siswa)

(sumber: Halloun \& Hestenes, 1985)

\section{Gambar 3. Soal Penguasaan Konsep Diagram Gerak Lurus}

Pada penelitian ini gerak dua dimensi, meliputi gerak parabola dan gerak melingkar. Pada gerak parabola penguasaan konsep dengan ranah kognitif C2 memiliki persentase tertinggi. Soal 12 ranah kognitif C2 materi gerak parabola ditunjukkan gambar 4. 44 siswa mampu menentukan vektor kecepatan dan percepatan dengan tepat saat disajikan diagram gerak parabola. Akan tetapi, pada soal 13, 43 siswa memilih jawaban pada gerak parabola kecepatan benda selalu konstan dan arahnya menyinggung lintasan. Sehingga ditemukan ketidakkonsistenan jawaban tentang vektor kecepatan. Pada gerak melingkar persentase tertinggi terdapat di ranah kognitif C3. Ranah kognitif C3 yang diuji adalah menentukan besar kecepatan maksimum benda bergerak pada lintasan melingkar. Penguasaan konsep siswa pada gerak melingkar lebih rendah dari penguasaan konsep siswa pada materi gerak lurus dan gerak parabola. Siswa mengatakan bahwa gerak melingkar lebih rumit dari pada gerak lurus maupun parabola. Hasil penguasaan konsep pada soal perhitungan matematis lebih tinggi daripada soal menganalisis vektor. Siswa mengatakan soal perhitungan lebih mudah karena jika mereka mengetahui persamaan yang digunakan maka mereka dapat mengerjakan soal dengan benar. Miskonsepsi gerak parabola dan gerak melingkar disajikan pada tabel 3.

Tabel 3. Ringkasan Miskonsepsi Konsep Gerak Dua Dimensi

\begin{tabular}{|l|l|l|}
\hline Konsep & Konsep yang dimiliki siswa & Persentase \\
\hline Diagram Gerak Parabola (Gambar 4.a) & Percepatan dipengaruhi ketinggian maksimum benda & $50 \%$ \\
\hline $\begin{array}{l}\text { Vektor kecepatan dan vektor percepatan pada gerak } \\
\text { parabola (Gambar 4.b) }\end{array}$ & Arah kecepatan selalu tegak lurus dengan arah percepatan & $38 \%$ \\
\hline $\begin{array}{l}\text { Vektor kecepatan dan vektor percepatan pada gerak } \\
\text { melingkar dengan kelajuan tetap }\end{array}$ & $\begin{array}{l}\text { Arah kecepatan rata-rata dapat ditentukan dengan cara membuat } \\
\text { panah dari posisi awal ke posisi akhir }\end{array}$ & $37 \%$ \\
& $\begin{array}{l}\text { Arah kecepatan rata-rata menuju pusat lintasan } \\
\text { Arah percepatan rata-rata menyinggung lintasan }\end{array}$ & $38 \%$ \\
\hline
\end{tabular}

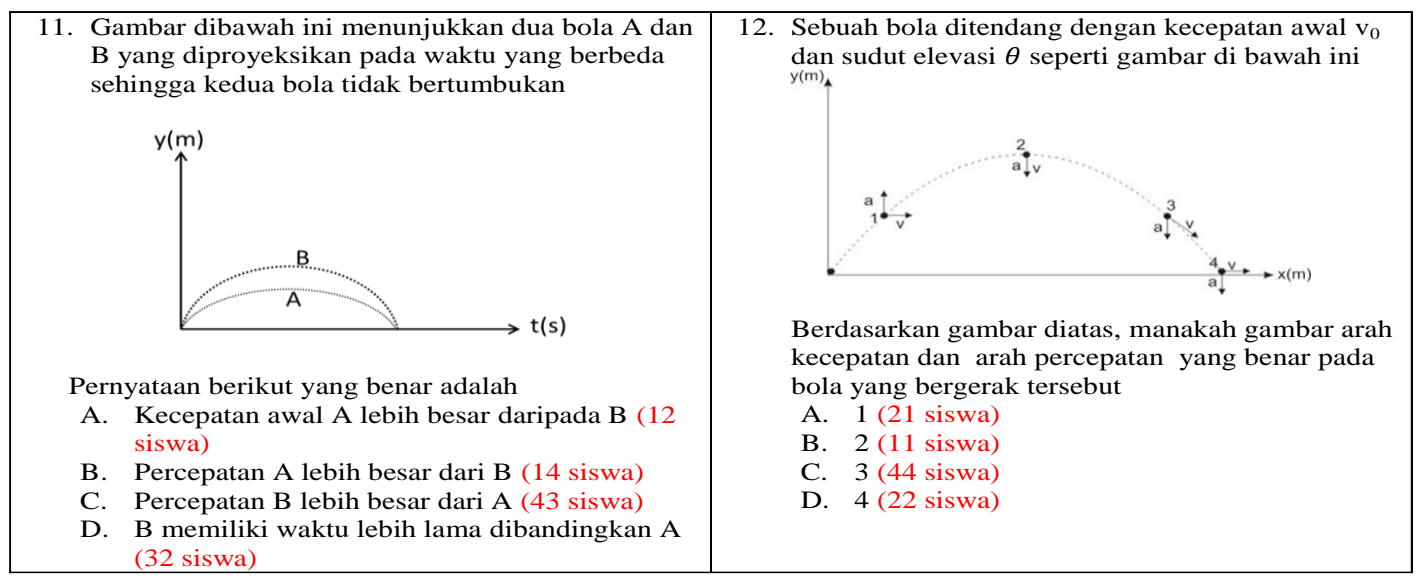

Gambar 4. Soal Penguasaan Konsep Gerak Parabola 


\section{PEMBAHASAN}

Penguasaan konsep gerak satu dan dua dimensi siswa SMA Negeri di Bojonegoro masih rendah. Sebagian siswa tidak mampu membedakan perpindahan dan jarak pada gerak lurus. Miskonsepsi tentang perpindahan dan jarak juga ditemukan pada penelitian (Hudha, dkk, 2016; Setyono, dkk, 2016) yaitu 33\% siswa menghitung perpindahan sama dengan menghitung jarak. Perpindahan merupakan besaran vektor yang hanya bergantung pada posisi awal dan posisi akhir benda (Knight, 2017). Penguasaan konsep perpindahan dan jarak yang rendah memengaruhi siswa dalam menentukan kecepatan rata-rata dari diagram gerak dua benda.

Siswa menganggap dua benda pada posisi yang sama memiliki kecepatan rata-rata yang sama pula. Kecepatan ratarata $\bar{v}_{x}$ adalah perpindahan benda $\Delta x$ selama selang waktu $\Delta t$ tertentu (Serway \& Jewett, 2014). Siswa tidak memperhatikan arah kecepatan dalam menentukan percepatan rata-rata benda yang bergerak lurus berubah beraturan. Padahal percepatan ratarata $\bar{a}_{x}$ merupakan perubahan kecepatan $\Delta v_{x}$ dibagi selang waktu $\Delta t$ dimana perubahan tersebut terjadi (Serway \& Jewett, 2014). Siswa tidak menggunakan konsep bahwa kecepatan merupakan besaran vektor (Hudha, dkk, 2016; Setyono, dkk, 2016). Sub topik arah vektor merupakan konsep tersulit bagi siswa (Sari, dkk, 2017). Penelitian (Wahyudi, dkk, 2013) juga menunjukkan bahwa guru mengalami miskonsepsi tentang konsep kecepatan tertukar dengan konsep kelajuan.

Pada soal menganalisis grafik ditemukan bahwa siswa menganggap grafik perpindahan terhadap waktu sebagai lintasan gerak. Pemahaman grafik sebagai lintasan gerak benda juga ditemukan pada penelitian (Beichner, 1994; Elby, 2000; Planinick, 2013). Siswa menentukan percepatan dengan persamaan $a=s / t^{2}$, kesulitan siswa dalam menentukan percepatan juga ditemukan pada penelitian (Setyono, dkk, 2016). Siswa mengalami miskonsepsi terkait hubungan gaya, kecepatan, dan percepatan (Rosenbaltt, dkk, 2011). Pada grafik kecepatan terhadap waktu siswa dapat menentukan percepatan. Percepatan merupakan gradien dari kecepatan (Kalman, dkk, 2018). Siswa memahami konsep percepatan merupakan perubahan kecepatan pada selang waktu tertentu (Afwa, dkk, 2016).

Siswa menganggap bahwa pada gerak parabola kecepatan gerak benda selalu tegak lurus dengan percepatannya. Miskonsepsi tentang vektor kecepatan dan vektor percepatan karena siswa tidak dapat membedakan vektor pada sumbu-x dan sumbu-y (Saepuzaman, 2016). Gerak parabola merupakan gabungan gerak lurus beraturan disumbu-x dan gerak lurus berubah beraturan pada sumbu-y (Serway \& Jewett, 2014). Gerak parabola pada sumbu-y merupakan gerak yang dipengaruhi oleh gravitasi (Wang, dkk, 2015). Percepatan pada gerak parabola nilainya sama dengan (-g) (Knight, 2017) dan selalu menuju pusat bumi. Namun, siswa berpendapat bahwa percepatan pada gerak parabola tergantung ketinggian maksimum yang dicapai benda. Vektor kecepatan selalu menyinggung lintasan (Knight, 2017) dengan kecepatan arah horizontal bernilai konstan. Kecepatan arah vertikal akan berkurang seiring bertambahnya ketinggian dan bernilai nol pada ketinggian maksimum (Wahyudi, dkk, 2013). Siswa dapat menggunakan persamaan gerak lurus dalam menentukan ketinggian maksimum benda dan jangkauan maksimum benda (Jordan, dkk, 2018).

Pada gerak melingkar dengan kelajuan konstan ditemukan beberapa kesulitan yang dialami siswa. Siswa kesulitan dalam menentukan vektor kecepatan dan percepatan. Kesulitan terkait menentukan arah percepatan pada lintasan melingkar juga ditemukan pada penelitian (Afwa, dkk, 2016; Sutopo, dkk, 2012). Pada gerak melingkar dengan kelajuan konstan, arah percepatan menuju pusat lintasan (Knight, 2017) karena percepatan tangensial bernilai nol (Afwa, dkk, 2016). Arah kecepatan pada gerak melingkar beraturan selalu menyinggung lintasan dengan kelajuan konstan (Serway \& Jewett, 2014).

\section{SIMPULAN}

Penguasaan konsep gerak satu dan dua dimensi siswa SMA Negeri di Bojonegoro masih rendah. Rata-rata siswa hanya mampu menjawab 5 dari 20 soal. Siswa mengalami miskonsepsi tentang jarak dan perpindahan pada gerak lurus. Siswa menganggap kurva grafik posisi terhadap waktu adalah lintasan gerak benda. Namun, siswa mampu menafsirkan gradien grafik kecepatan terhadap waktu sebagai percepatan. Siswa menganggap percepatan pada gerak parabola tidak konstan. Siswa kesulitan menentukan vektor kecepatan dan percepatan pada gerak parabola maupun gerak melingkar. Saran untuk penelitian selanjutnya adalah mengembangkan instrumen soal penguasaan konsep tentang diagram gerak, grafik, dan vektor pada gerak satu dan dua dimensi. Selain itu, peneliti selanjutnya dapat menerapkan model pembelajaran dengan fokus pada miskonsepsi gerak satu dan dua dimensi.

\section{DAFTAR RUJUKAN}

Adams, W. K., \& Wieman, C. E. (2015). Analyzing The Many Skills Involved in Solving Complex Physics Problems. American Journal of Physics, 83(5), 459-467.

Afwa, I. L., Sutopo, S., \& Latifah, E. (2016). Deep Learning Question untuk Meningkatkan Pemahaman Konsep Fisika. Jurnal Pendidikan: Teori, Penelitian, dan Pengembangan, 1(3), 434-447.

Anderson, O. W. \& Krathwohl, D. R. (2001). A Taxonomy for Learning, Teaching, and Assessing: A Revision of Bloom's Taxonomy of Educational Objectives. New York: Longman.

Beichner, R. J. (1994). Testing Student Interpretation of Kinematics Graphs. American journal of Physics, 62(8), 750 - 762.

Bollen, L., De Cock, M., Zuza, K., Guisasola, J., \& van Kampen, P. (2016). Generalizing a Categorization of Students' Interpretations of Linear Kinematics Graphs. Physical Review Physics Education Research, 12(1), 010108. 
Ceberio, M., Almudí, J. M., \& Franco, Á. (2016). Design and Application of Interactive Simulations in Problem-Solving in University-Level Physics Education. Journal of Science Education and Technology, 25(4), 590 - 609.

Dilber, R., Karaman, I., \& Duzgun, B. (2009). High School Students' Understanding of Projectile Motion Concepts. Educational Research and Evaluation, 15(3), 203-222.

Docktor, J. L., \& Mestre, J. P. (2014). Synthesis of Discipline-Based Education Research in Physics. Physical Review Special Topics-Physics Education Research, 10(2), 020119.

Docktor, J. L., Strand, N. E., Mestre, J. P., \& Ross, B. H. (2015). Conceptual Problem Solving in High School Physics. Physical Review Special Topics-Physics Education Research, 11(2), 020106.

Elby, A. (2000). What Students' Learning of Representations Tells us about Constructivism. The Journal of Mathematical Behavior, 19(4), 481-502.

Engelhardt, P.V., \& Beichner, R. J. (2004). Student' Understanding of Direct Current Resistive Electrical Circuits. American Journal of Physics, 72(1), 98-115.

Hudha, M. N., Yuliati, L., \& Sutopo, S. (2016). Perubahan Konseptual Fisika dengan Authentic Problem melalui Integrative Learning pada Topik Gerak Lurus pada SMA Suryabuana Malang. Jurnal Inspirasi Pendidikan, 6(1), 733 -743.

Ivanjek, L., Susac, A., Planinic, M., Andrasevic, A., \& Milin-Sipus, Z. (2016). Student Reasoning about Graphs in Different Contexts. Physical Review Physics Education Research, 12(1), 010106.

Jordan, C., Dunn, A., Armstrong, Z., \& Adams, W. K. (2018). Projectile Motion Hoop Challenge. The Physics Teacher, 56(4), $200-202$.

Kalman, C. S., Lattery, M., \& Sobhanzadeh, M. (2018). Impact of Reflective Writing and Labatorials on Student Understanding of Force and Motion in Introductory Physics. Creative Education, 9(4), 575-596.

Knight, R. D. (2017). Physics For Scientists and Engineers Second Edition A Strategyc Approach. Pearson San Francisco.

McDermott, L. C., Rosenquist, M. L., \& Van Zee, E. H. (1987). Student Difficulties in Connecting Graphs and Physics: Examples from Kinematics. American Journal of Physics, 55(6), 503-513.

Meltzer, D. E. (2011). Teacher Education in Physics: Research, Curriculum, and Practice. American Physical Society.

Millar, R., \& Kragh, W. (1994). Alternative Frameworks or Context-Specific Reasoning?: Children's Ideas about the Motion of Projectiles. School Science Review, 75(272), 27-34.

Montecinos, A., Davis, S., \& Peralta, J. (2018). Deterministic Physical Systems Under Uncertain Initial Conditions: The Case of Maximum Entropy Applied to Projectile Motion. European Journal of Physics.

Pawl, A. (2014). Is it Disadvantageous to Teach Forces First in Mechanics. American Association of Physics Teachers, $1119(10), 203-206$.

Planinic, M., Ivanjek, L., Susac, A., \& Milin-Sipus, Z. (2013). Comparison of University Students' Understanding of Graphs in Different Contexts. Physical Review Special Topics-Physics Education Research, 9(2), 020103.

Reif, F., \& Allen, S. (1992). Cognition for Interpreting Scientific Concepts: A Study of Acceleration. Cognition and Instruction, 9(1), 1-44.

Rosenblatt, R. \& Heckler, A. F. (2011). Systematic Study of Student Understanding of the Relationships Between the Directions of Force, Velocity, and Acceleration in One Dimension. Phys. Rev. St Phys.Educ. Res., 7, 020112.

Saepuzaman, D., \& Karim, S. (2016). Desain Pembelajaran Student's Conceptual Construction Guider Berdasarkan Kesulitan Mahasiswa Calon Guru Fisika pada Konsep Gerak Parabola. Jurnal Penelitian \& Pengembangan Pendidikan Fisika, 2(2), 79-86.

Serway, R. A., \& Jewett, J. W. (2014). Physics for Scientist and Engineers with Modern Physics $9^{\text {th }}$ Edition. United States of America: Thomson Higer Education.

Setyono, A., Nugroho, S. E., \& Yulianti, I. (2016). Analisis Kesulitan Siswa dalam Memecahkan Masalah Fisika Berbentuk Grafik. UPEJ Unnes Physics Education Journal, 5(3), 32-39.

Sutarno, S., Setiawan, A., Kaniawati, I., \& Suhandi, A. (2017). Pre-Service Physics Teachers' Problem-Solving Skills in Projectile Motion Concept. In Journal of Physics: Conference Series, 895(1), 012105. IOP Publishing.

Sutopo, S. 2012. Pembelajaran Kinematika Berbasis Diagram Gerak: Cara Baru Dalam Pengajaran Kinematika. Seminar Nasional Penelitian Universitas Negeri Yogyakarta, (June 2012), 11.

Sutopo, Liliasari, Waldrip, B., \& Rusdiana, D. (2012). Impact of Representational Approach on The Improvement of Students' Understanding of Acceleration. Jurnal Pendidikan Fisika Indonesia, 8(2), 161-173.

Taqwa, M. R. A., Hidayat, A., \& Sutopo, S. (2017). Konsistensi Pemahaman Konsep Kecepatan dalam Berbagai Representasi. Jurnal Riset dan Kajian Pendidikan Fisika, 4(1), 31-39.

Wahyudi, I., \& Maharta, N. 2013. Pemahaman Konsep dan Miskonsepsi Fisika pada Guru Fisika SMA RSBI di Bandar Lampung. Jurnal Pendidikan MIPA Universitas Lampung, 14(1).

Wang, J., Guo, D., \& Jou, M. (2015). A Study on the Effects of Model-Based Inquiry Pedagogy on Students' Inquiry Skills in a Virtual Physics Lab. Computers in Human Behavior, 49, 658-669. 